\title{
The Corporation As Time Machine: Intergenerational Equity, Intergenerational Efficiency, and the Corporate Form
}

\author{
Lynn A. Stout*
}

\begin{abstract}
This Symposium Article argues that the board-controlled corporation can be understood as a legal innovation that historically has functioned as a means of transferring wealth forward and sometimes backward through time, for the benefit of present and future generations. In this fashion the board-controlled corporation promotes both intergenerational equity and intergenerational efficiency. Logic and evidence each suggest, however, that the modern embrace of "shareholder value" as the only corporate objective and "shareholder democracy" as the ideal of corporate governance is damaging the corporate form's ability to serve this economically and ethically important function.
\end{abstract}

\section{INTRODUCTION}

We are mortal creatures; we grow old and die. That hard truth carries a number of fundamental implications about the nature and objectives of individual human beings. It also carries a number of fundamental implications about the nature and objectives of an entity that (unlike human beings) need not grow old and die: the corporation.

This Symposium Article explores the possibility that mortal persons use the corporate entity to transport wealth between different time periods in two different ways. First, as a legal entity with the capacity to own assets in its own name, the corporation allows human persons to transfer

\footnotetext{
* Distinguished Professor of Corporate and Business law, Clarke Business Law Institute, Cornell Law School. Earlier versions of this Symposium Article were presented at workshops at Cornell Law School, the annual meeting of the Gruter Institute, and Seattle University School of Law's annual Berle Symposium. The author is grateful to the participants at those events for their comments and observations. She would also like to give special thanks to David Ciepley, Martin Lipton, Sergio Gramitto Ricci, Andrew Schwartz, and Leo Strine for their insights and suggestions and Chuck O'Kelley for his encouragement and support.
} 
resources to the corporate entity and make them unavailable for current consumption ("asset lock-in") so that the resources can be instead invested in projects that generate wealth in later time periods. This future wealth may be consumed by the human persons who originally committed resources to the corporate entity. But the future wealth generated by a corporation with perpetual life can also be consumed by a future generation of human beings. Thus the corporate form offers not only a useful savings and investment technology for individuals seeking to serve their own interests, but also a vehicle for the present generation to altruistically pass resources forward through time to benefit those who will live in the future.

Second, some types of corporations - in particular, public business corporations with freely transferable shares traded on a reasonably efficient market - can transform wealth that will be generated in the future into wealth that can be enjoyed today in the form of a higher share price. This means the corporate form can be used not only to create future wealth to benefit future generations, but also to shift wealth backward in time to benefit earlier generations. This allows a kind of implicit exchange between those who live presently and those who will live in the future, rewarding the present generation of shareholders for preserving resources and making investments that benefit future generations.

The public business corporation with asset lock-in, perpetual life, and freely transferable shares, accordingly, is a legal technology that can play, and historically has played, an important role in promoting both intergenerational equity and intergenerational efficiency. However, the recent rise of a "shareholder value"-focused approach to understanding and governing public corporations has begun to erode public companies' abilities to lock in their assets. Logic and evidence both suggest this loss of asset lock-in is threatening the public corporation's ability to serve as a mechanism for transferring wealth between time periods and generations.

Part II of this Symposium Article describes how corporate entities can be understood as institutions designed to transfer wealth forward from earlier time periods to later time periods. Part III explains how the process can work in reverse, with public business corporations in particular shifting wealth from the future to the present. Part III also explains how this backwards time-shifting encourages the current generation to preserve and invest resources in a fashion that serves both intergenerational equity and intergenerational efficiency. Part IV offers some thoughts and evidence on the destructive consequences of the contemporary shareholder value approach to corporations and corporate governance. Part V concludes. 


\section{HOW CORPORATIONS SHIFT WEALTH FROM THE PRESENT TO THE FUTURE}

\section{A. On the Need for a Savings/Investment Technology}

One of the many problems we face as humans is our need for a savings technology. Most of us are productive in youth and middle age and generate wealth beyond what we need for immediate consumption. But if we are lucky enough to escape disease and accident, we may live past the point where we can easily provide for our own needs. Moreover, even in youth and middle age, we see both fat years and lean. We need a technology to preserve (and ideally increase) the excess wealth we generate in good times so that it can be available to us in bad years and in our decline. $^{1}$

Unfortunately, a good savings technology is hard to find. Primitive populations did their best to preserve meat and grain. But smoked meat and stored grain eventually rot. Today, many of us store wealth in fiat money or (for the more nervous) precious metals. Unfortunately, these are also flawed saving strategies, as inflation typically eats away the value of what we have saved, as surely as mold and mice eventually destroy wheat in a granary. ${ }^{2}$

To preserve and (better yet) increase saved resources, we must invest those resources and put them to work in some endeavor that generates future returns. A Roman farmer, for example, might plant olive trees to bear fruit to sustain him in his old age. But this is investment on a relatively modest scale.

\section{B. The Corporation as Savings/Investment Technology That Locks In Assets}

By allowing individuals to aggregate their resources and invest them collectively, corporations allow people to pursue saving/investment projects much larger than planting an orchard. Through aggregation in a corporate entity, individuals of modest means can accumulate enormous sums of capital that can be devoted to enormous ventures that promise

1. Saving and investing is one strategy for ensuring that one has access to resources in hard times or after one's productivity has declined. Another strategy is to rely on altruism - the kindness of one's family or community or even, in the fashion of Blanche DuBois, the kindness of strangers. However, the empirical evidence generally suggests that human altruism is limited. See infra notes 39-40 (discussing altruism). Thus, a good savings/investment technology remains highly desirable.

2. Central banks typically try to maintain a modest degree of inflation to avoid any risk of deflation, which is viewed as far more dangerous. See Rick Newman, Why Deflation is Worse Than Inflation, U.S. NEWS \& WORLD REP. (July 16, 2010, 10:16 AM), http://money.usnews.com/money/ blogs/flowchart/2010/07/16/why-deflation-is-worse-than-inflation. 
even more enormous returns. They can build railroads and manufacturing plants or create banks and pharmaceutical businesses. Thus the invention of the corporate entity increased the number and types of projects individual persons could undertake in their quest to invest resources for future consumption. ${ }^{3}$

But there are other legal technologies, beyond the corporate form, that aggregate wealth. Partnerships in particular also permit aggregation. To understand the unique advantages of the corporate entity ${ }^{4}$ as a savings/investment technology, we must focus on an attribute of the corporate form that partnerships typically lack: the ability to lock in resources contributed by shareholders.

My coauthor Margaret Blair has used the phrase "lock-in" to describe how corporate assets, because they are the property of the corporate entity and not its shareholders, cannot be easily withdrawn from the entity, even when a shareholder or group of shareholders wants to do this. ${ }^{5}$ Put simply, once you use your money to purchase stock in a company, your money becomes the company's money. You have no legal power to demand it back.

On first inspection, asset lock-in seems a disadvantage. It raises a number of potential problems, including the risk that locked-in assets will be kept inside the corporation even when they could be put to better use elsewhere. ${ }^{6}$ As discussed further below, however, asset lock-in also offers economic advantages by making it possible for corporate entities

3. Because borrowing allows the borrower to obtain money now in exchange for payment later, the debtor/creditor relationship similarly can be viewed as an innovative savings technology, albeit a relatively ancient one. See DAVID GRAEBER, DEBT: THE FirST 5000 YeARS (2011).

4. This category can include the business form known as the limited liability company or LLC. See infra note 7 (discussing LLCs).

5. See Margaret M. Blair, Locking In Capital: What Corporate Law Achieved for Business Organizers in the Nineteenth Century, 51 UCLA L. REV. 387 (2003). Corporations can lock in assets because unlike traditional partnerships, they own assets in their own names. Shareholders are entitled only to dividends, which are paid only when the board of directors declares a dividend and the law permits the dividend to be paid. Margaret M. Blair \& Lynn A. Stout, A Team Production Theory of Corporate Law, 85 VA. L. REV. 247, 292 (1999).

However, when a corporation has a controlling shareholder, that controlling shareholder may have the functional ability to gain access to the corporation's assets by virtue of her power to easily replace the members of the board of directors. Thus, corporations with controlling shareholders have less capacity for asset lock-in. Id. at 319; see also infra notes 9-10 and accompanying text (discussing corporations with controlling shareholders).

It should also be noted that corporate "stakeholders" like employees or executives sometimes acquire substantial power to extract corporate assets for their own benefit. Excessive stakeholder power to extract corporate assets can also defeat lock in and threatens the corporation's ability to pursue long-term projects. See infra note 91 (discussing decline of the U.S. auto industry due to unionized employee demands).

6. See infra notes $60,62-66$ and accompanying text (discussing agency costs). 
(a category that today includes many LLCs) ${ }^{7}$ to pursue long-term economic projects under uncertain conditions - projects that otherwise could not succeed.

\section{A Caveat on the Availability of Asset Lock-In: Not All Corporations Are Alike}

Before considering the possible economic advantages of asset lockin, it should be pointed out that while all corporations hold assets in their own names, and while shareholders generally lack legal access to corporate assets ${ }^{8}$ in certain kinds of corporations some shareholders, as a practical matter, can unlock corporate assets and take those assets for themselves. ${ }^{9}$ In particular, it is much harder to lock assets into a corporation that has a controlling shareholder. A controlling shareholder enjoys indirect power to extract corporate assets because she can easily remove and replace the company's board of directors if they do not follow her instructions. Only as directors become independent of shareholders does asset lock-in become possible. ${ }^{10}$

7. An LLC can be structured today to function very much like a traditional corporation, with perpetual life, capital lock-in, and free transferability of shares. Thus, some LLCs are the functional equivalents of close corporations, with the only significant difference being tax consequences (LLCs have the option to "check the box" and receive partnership tax treatment, so they are not subject to income tax at the level of the entity). However, an LLC whose shares are listed for trading on a recognized exchange loses the option of pass-through tax treatment, which is the primary distinction between an LLC and a corporation-becoming a public corporation in all but name. See 26 U.S.C. § 7704 (2014).

8. Owning shares in Apple does not entitle you to help yourself to the wares in an Apple store. Shareholders may only access corporate assets by receiving dividends or selling their shares back to the firm. Moreover, dividends and share repurchases are controlled not by shareholders, but by the board of directors. DEL. CODE ANN. tit. 8, §§ 151, 160, 170 (2014).

9. In other words, simply creating a corporate entity is not sufficient to achieve lock-in.

10. As this sentence implies, asset lock-in is not a binary characteristic. Corporate entities can be viewed as falling along a spectrum. At one end of the spectrum, nonprofit corporations with no shareholders have an extreme degree of asset lock-in. At the other end of the spectrum, a corporation with only one shareholder who can easily remove the board has very little lock-in unless that sole shareholder is prevented from withdrawing corporate assets by other constraints, for example debt covenants that limit dividends and share repurchases.

Most corporate entities fall somewhere between these two extremes on the lock-in spectrum. For example, a publicly traded firm with disbursed share ownership and strong antitakeover protections has a high degree of lock-in, as it is difficult or impossible for shareholders to demand cash from the corporation through dividends, share repurchases, or the sale of the firm.

Put differently, as Blair and I explained in detail in the article that is the subject of this Symposium, a greater degree of board control increases a corporate entity's ability to lock in its assets because the board is free to act as a "mediating hierarch" precluded by law from taking the corporate entity's assets for its own benefit. Unlike shareholders, a board structured to act like a mediating hierarch does not benefit from unlocking corporate assets before the corporation's long-term goals have been achieved. Placing control of the firm in the hands of a board can thus increase the odds of 
In the United States today, the vast majority of corporate entities (again, this category includes many LLCs) are small firms whose shares are not traded on an exchange. Many of these small entities may have a controlling shareholder. In such cases, the entity's capacity to lock in assets is questionable, and its ability to pursue long-term projects depends on the patience and dedication of the shareholder in question.

However, even if many (perhaps most) corporate entities cannot lock in assets, some especially important kinds of corporations can. These include nonprofit corporations that have no shareholders; private companies with multiple shareholders who share control $;{ }^{11}$ and the canonical public company with widely disbursed share ownership, especially if that public company has takeover defenses that make it unlikely to acquire a controlling shareholder. Control over the assets of these entities rests mostly in the hands of boards of directors. And boardcontrolled entities, while perhaps fewer than corporations with a controlling shareholder, account for far more economically important firms, including all major nonprofits and most Fortune 500 companies. Nor is this a coincidence. Only entities that can aggregate resources from many individuals and then lock in and preserve those resources for long periods of time are likely to survive to grow to enormous size.

The predictable outcome is that corporations with a high degree of board control, and so a high degree of lock-in, play disproportionately important roles in our economy and our society. The remainder of this Symposium Article focuses on the economic functions of corporations with effective asset lock-in.

\section{Asset Lock-In Encourages Investment by Protecting Shareholders from Each Other}

Let us first consider an important but counterintuitive advantage of locking assets into a corporate entity: it encourages aggregated investment by reducing shareholders' risk that they will harm each other. To

\footnotetext{
the corporation's long-term survival. See Blair \& Stout, supra note 5, at 284-85 (discussing idea of board as mediating hierarch).

11. Most corporate statutes once required corporations to have three or more shareholders, essentially mandating some degree of board control and asset lock-in as a prerequisite for employing the corporate form. 1A William MEAde Fletcher ET AL., FLETCHER CyClopedia OF THE LAW OF CORPORATIONS $\S 88$ (2010). Modern statutes often allow corporations to be formed with a single shareholder. DEL. CODE ANN. tit. 8, § 101 (2011). The fact that corporations with a single shareholder lack equity aggregation or board control raises the question of what economic function incorporation serves in such cases. Limited shareholder liability that encourages risk taking seems the obvious answer. See infra note 45 (discussing shareholder limited liability as an explanation for the rise of the corporate form).
} 
understand that risk, imagine a railroad company that lacked asset lockin, so that each shareholder could withdraw her proportionate interest in the railroad's assets at any time, just as partners can withdraw their interest from a partnership. Such a railroad would be constantly exposed to the danger that a significant shareholder might demand the return of her interest. Unless the railroad happened to have a lot of cash on hand, it might be forced to sell essential assets to meet such a demand, destroying the value of the enterprise. And, as Blair has explained, shareholders might very well make such demands, either because they suddenly find themselves in need of cash or, more opportunistically, because they hope making a demand that threatens the enterprise will give them leverage to extract valuable concessions from their fellow shareholders. ${ }^{12}$ Alternatively, as Henry Hansmann and Reinier Kraakman have pointed out, the creditors of a shareholder who becomes insolvent might make similar claims. ${ }^{13}$

The corporate entity's capacity to aggregate and lock in assets and insulate them from the demands of shareholders (or shareholders' creditors) accordingly gives board-controlled corporations an important advantage as a savings/investment technology. Unlike partnerships, which can be destroyed by the death, withdrawal, or bankruptcy of any one of the partners, ${ }^{14}$ corporations can "stay the course" and pursue large-scale, long-term projects under uncertain conditions without fearing their equity investors might become opportunistic, impatient, or insolvent. This encourages shareholders to invest in collective enterprises by protecting shareholders from each other, expanding the range of economic projects individuals can pursue in their quest to ensure they have access to wealth in the future.

\section{E. Asset Lock-In Also Encourages Stakeholder Investment by Protecting Stakeholders from Shareholders}

In the 1999 article that is the subject of this Symposium, ${ }^{15}$ Blair and I explored how creating a board-controlled corporation with asset lock-in does more than protect shareholders from each other. It also offers a se-

\footnotetext{
12. Blair, supra note 5, at 401.

13. Henry Hansmann \& Reinier Kraakman, The Essential Role of Organizational Law, 110 YALE L.J. 387, 394 (2000).

14. The death or withdrawal of a partner (including withdrawal due to insolvency) typically ends a general partnership. UNIF. P'SHIP ACT $§ 31$ (1914). Some partnership agreements ensure the partnership continues by providing that the remaining partners must purchase the interests of any partner who leaves. $I d$. $\S 38$. This solution only works when the remaining partners have the resources to purchase the ex-partner's interest.

15. Blair \& Stout, supra note 5.
} 
cond economic advantage by protecting important corporate stakeholders $^{16}$ - employees, customers, suppliers, creditors-from the corporation's shareholders. What's more, Blair and I argued, protecting stakeholders this way, while sometimes costly to shareholders ex post, actually may provide greater benefits to shareholders ex ante by promoting what economists call "team production."

To understand this somewhat counterintuitive idea, consider again the case of a corporation founded to build a railroad, as many early business corporations were founded to do. Once the railroad's assets are locked into a board-controlled corporate entity, shareholders cannot easily withdraw their financial contributions. This may prove a serious inconvenience to the railroad's shareholders ex post, should they want or need to convert their interest to cash. But it also makes it far safer for the corporate entity to convert shareholders' financial contributions to railroad-"specific" assets, like track or rights-of-way, ${ }^{17}$ and makes the company's survival more likely. ${ }^{18}$ This encourages important stakeholders to make their own firm-specific investments: customers become willing to buy houses along the railroad and use it for their daily commute; employees become willing to acquire skills of unique value to the railroad as an employer; and communities become willing to build infrastructure along the line to support and attract businesses that will use the railroad. These railroad-specific stakeholder investments contribute to the enterprise's success. Asset lock-in, by protecting stakeholders from the risk that shareholders will try to withdraw assets from the corporate "team," ultimately benefits shareholders as well. ${ }^{19}$

16. This Symposium Article uses the word "stakeholder" to refer to nonshareholder groups that contribute valuable resources (labor, expertise, financing, infrastructure) to support corporate operations. There may be groups that do not contribute to the company's success that nevertheless are affected by the corporation's actions. For example, a corporation that pollutes may harm parties with no other relationship to the firm. For clarity, this Symposium Article will not use the word stakeholders to describe such groups, but instead employs the phrase "corporate externalities" to describe situations where the corporation imposes costs on or provide benefits to parties who otherwise have no relationship with the firm.

17. In the parlance of economics, a resource is described as specific to a particular project when it cannot be withdrawn from the project and sold on the market without losing much of its value. See Blair \& Stout, supra note 5, at $272 \mathrm{n} .51$ (discussing asset specificity).

18. Corporate survival is more likely when corporate assets are controlled by a board of directors because directors are precluded by the fiduciary duty of loyalty from taking corporate assets for themselves. Shareholders in contrast are permitted to receive corporate assets distributed through dividends, share repurchase programs, and liquidations. See supra note 10 and accompanying text (discussing shareholders' incentives to unlock corporate assets).

19. Because the assets of a corporation with a controlling shareholder are not well locked-in, see supra text accompanying note 10 , this raises the question of how such corporations attract specific investments from stakeholders. Blair and I suspect interpersonal trust between stakeholders and controlling shareholders may provide part of the answer. See Blair \& Stout, supra note 5, at 302 
As this example illustrates, and as Blair and I explored in our 1999 article, recognizing stakeholders' specific investments reinforces how dangerously misleading it can be to describe the shareholders of a boardcontrolled company that is being operated rather than liquidated as the sole "residual claimants" in the corporation. ${ }^{20}$ An operating corporation as a matter of law is its own residual claimant, and the board of a public company typically enjoys a wide range of discretion to decide which of many corporate constituencies benefits from, or is harmed by, corporate actions and decisions. ${ }^{21}$ Boards might use their control over corporate assets to pay shareholders more or fewer dividends, but they might also give employees more or fewer raises and benefits, provide customers better or worse products and service, give executives greater or lesser job security and luxury perquisites, force creditors to bear more or less risk, and pay governments more or less in taxes. ${ }^{22}$

By emphasizing how taking account of stakeholders' interests ultimately benefits shareholders, team production analysis supports stakeholder theorists who have long argued that corporations are run well and contribute most to society when directors pay attention to corporate constituencies beyond equity investors. ${ }^{23}$ But team production theory also, as will be discussed later on, carries some interesting implications for how corporate entities transmute the relationship between present and future

(discussing close corporations); Margaret M. Blair \& Lynn A. Stout, Trust, Trustworthiness, and the Behavioral Foundations of Corporate Law, 149 U. PA. L. REV. 1735 (2001) (discussing trust in corporations).

20. Blair \& Stout, supra note 5, at 263. The problem of external costs provides an additional argument against viewing shareholders as the only parties that benefit from or are harmed by the board's business decisions.

21. Id.; See also Lynn A. Stout, The Shareholder Value Myth: How Putting SHAREHOlders First HaRms InVESTORS, Corporations, AND the Public (2012).

22. As an example of how governments are affected by corporate policies, consider the current debate over the decisions of several U.S. companies to avoid paying American corporate tax by pursuing "inversion" transactions that result in their becoming foreign companies. See David Gelles, Senate Panel Takes on Tax Inversions, BOSTON GloBe (July 23, 2014), https://www.bostonglobe.com/business/2014/07/22/senate-panel-takes-tax-inversions/kiSzBQQkvK 4N7nbxdKsmQI/story.html.

23. There is a longstanding debate among corporate scholars over whether corporations should be run to serve only the interests of shareholders (the dominant shareholder primacy approach, see infra Part IV.A), or whether they should also serve the interests of stakeholder groups like employees, customers, creditors, and society, see generally H. Jeff Smith, The Shareholders vs. Stakeholders Debate, 44 MIT SLOAN MGMT. Rev., no. 4, Summer 2003, at 85, available at http://sloanreview.MIT.edu/article/the-shareholders-vs-stakeholders-debate. This Symposium Article does not take a position beyond noting that once one recognizes that shareholders are not the only group affected by corporate decisions, see STOUT, supra note 21, at 4-6, stakeholder theorists would seem to have the intellectual high ground. Rather, this Symposium Article focuses on the particular problem of creating efficient incentives for the current generation (whether of shareholders or of shareholders and stakeholders) to set aside and invest resources to benefit future generations. 
generations. These include implications about how corporations can benefit future stakeholders as well as future shareholders, and implications about how present-day stakeholders as well as present-day shareholders can put these future benefits at risk by seeking to unlock corporate assets. $^{24}$

\section{F. Now, Add Perpetual Existence}

Corporations, as we have seen, can not only aggregate assets but can also lock those assets in against shareholders' (or, for that matter, stakeholders') demands. As we have also just seen, asset lock-in encourages shareholders and stakeholders alike to make specific investments in corporate production. These advantages of using the corporate form help explain why board-controlled corporate entities, both for-profit and nonprofit, have emerged as such important forces in our economy today. (Of course, placing control over corporate assets in the hands of a board rather than the corporation's shareholders or stakeholders raises its own problems. Part III discusses the issue of managerial "agency costs" in greater detail. $)^{25}$

There may be another reason, however, why board-controlled corporations have come to play such a central role in our economic system. So far, the analysis has focused, at least implicitly, on how corporate entities serve the interests of shareholders and stakeholders who are alive today. This focus is typical of most contemporary corporate scholarship, including much of my own. ${ }^{26}$ (After all, it is only the living whom we can see: out of sight, out of mind.) Yet the understandable human tendency to focus on the welfare of those living today when analyzing institutions may distract us from perceiving what may be the most important function of the corporate form. This function is hinted at when we consider another fundamental characteristic of corporate entities: perpetual life. $^{27}$

24. For simplicity, the discussion here will focus primarily on the relationship between the current generation of shareholders deciding whether to keep assets locked into a corporate entity, and future generations of shareholders who might benefit from such commitments. But see infra notes 72-73 and accompanying text (discussing how corporations can benefit future stakeholders) and supra note 5 (discussing how stakeholders can threaten to unlock corporate assets, just as shareholders can).

25. See infra Part III.

26. For an interesting recent exception, see Andrew A. Schwartz, The Perpetual Corporation, 80 GEO. WASH. L. REV. 764 (2012) (arguing that the corporate characteristic of perpetual life obliges managers to invest for a perpetual future, adopting long time horizons and low discount rates).

27. Two other characteristics often associated with corporate entities are limited liability and centralized management. See supra note 7 and infra note 45 for a discussion of these characteristics. 
Unlike a human being, a corporation need not grow old and die. At least in theory, it can exist in perpetuity. ${ }^{28}$ The remainder of this Symposium Article considers how the corporate entity's capacity to lock in assets may have even more interesting, and possibly more important, implications when considered in combination with the corporation's capacity to exist in perpetuity. As we have seen, asset lock-in allows corporations to pursue long-term economic projects that sole proprietorships and partnerships cannot. This expands the menu of savings/investment options available to human beings hoping to make wealth available to their future selves. But in addition to serving as a superior savings/investment technology for the present generation, the corporation can also preserve resources for, and pursue projects whose benefits will only be enjoyed by, future generations. Indeed, history suggests this is why many of the first corporations were created.

\section{G. Intergenerational Equity and How Corporations Can Preserve and Grow Resources for Future Generations}

Human beings are mortal, but human beings also reproduce. Each generation is replaced by another. This reality of our existence as biological organisms raises a number of significant issues. One is the question of equity between generations.

What obligations do the present generation owe to future generations? A full discussion of this difficult ethical issue lies well beyond the scope of this Symposium Article. But I take as my starting point that the present generation has some obligation to consider the welfare of those who come after us. Quite apart from efficiency concerns, most of us think it inequitable for the people who happen to be alive this moment to take for themselves all that can possibly be extracted from our economic, social, and ecological systems, and leave behind a burnt cinder.

Yet even if most people agree that equity demands we leave something behind for future generations, economic theory teaches that, collectively, we find it difficult to fulfill that ethical obligation. From the perspective of the individual, the ethical desire to leave resources for future generations presents a classic "tragedy of the commons." ${ }^{29}$ The individu-

28. More accurately, a corporation can exist "in sempiternity," meaning that while the corporation is not eternal (having no beginning nor end in time), it is created and so has a beginning in time, but thereafter no end in time. See David Ciepley, The Corporate Roots of the Liberal Democratic State 26 (July 28, 2014) (unpublished manuscript) (draft on file with author) (discussing corporate sempiternity).

29. See Garrett Hardin, The Tragedy of the Commons, 162 SCI. MAG. 1243 (1968), available at http://www.sciencemag.org/content/162/3859/1243.full. 
al who abstemiously refrains from consuming every resource he can lay his hands on during his lifetime will, on the margin, accomplish little more than to reduce his own welfare. Someone else, either in this generation or in the next, will selfishly take what he does not.

Altruism toward those who will live in the future, like other forms of charity, is a public good that will be underprovided absent intervention. To preserve resources and invest in projects that benefit future generations, we need some mechanism to take the decision whether to consume or invest away from the individual.

One obvious mechanism is a coercive state. From the days of the Pharaohs and the pyramids, states have played important roles in promoting large-scale, long-term enterprises. But government has its limits as a mechanism for protecting the interests of future generations. As both democracy and capitalism have spread, the ability of states to protect the interests of those not yet born has become, if anything, more questionable. Capitalism, with its emphasis on private ordering, discourages state intervention in economic production. And democracy strongly privileges the interests of the current generation of voters over the interest of voters not yet born. ${ }^{30}$ Thus it seems worthwhile to pay some attention to a second possible way to take the decision to consume or to invest resources away from the individual: create a corporation.

\section{H. Perpetual Life Makes the Corporation a Technology for Preserving and Transferring Resources to Future Generations}

Corporate perpetual life has important consequences. Most obviously, unlike a mortal human being, a corporate entity gains no advantage from consuming its resources within a relatively brief time frame. It can afford to be patient. This makes corporations ideal institutions for pursuing long-term projects whose benefits will not be realized until well after the current cohort of human beings has ceased to exist.

In fact, preserving resources and pursuing long-term projects for future generations were exactly what some of the earliest corporationsamong them townships, universities, and monasteries - were created to do. It was a corporate entity, the Veneranda Fabbrica del Duomo di Mi-

30. In less democratic systems, despots and aristocrats whose material needs are well satisfied might be more inclined to pursue future-oriented projects that allow them to leave an altruistic legacy than the typical voter whose focus may be on meeting immediate needs. The spread of political democracy around the globe may be making it more difficult for states to invest for the future, just as this Symposium Article argues the spread of shareholder democracy may be making it more difficult for public corporations to invest for the future. See infra text accompanying notes 93, 107 (discussing shareholder democracy). 
lano, that began building - and is still completing - the Cathedral of Milan, a project that has spanned thirty human generations. ${ }^{31}$ Similarly, when Oxford University's New College was first founded in 1379, the college dining hall was built using massive oak beams to hold up the roof because oak is a long-lasting timber. ${ }^{32}$ Only hundreds of years later did the oak beams begin to give out. ${ }^{33}$ New College was able to obtain new oak to rebuild the dining hall without difficulty because hundreds of years earlier it had acquired a grove of oak trees, which it had kept and allowed to grow to maturity. ${ }^{34}$

Such examples illustrate how corporate entities can surpass mere human beings in their ability to plan and implement projects whose benefits will be reaped decades, even centuries, after the project is begun. This capacity to benefit future generations is perhaps most obvious in the case of nonprofit corporate entities like the Fabbrica and New College, or to use examples of corporations created more recently, the Nature Conservancy and Cornell University. But for-profit corporate entities also have perpetual life.

History offers many examples of how, under the right circumstances, for-profit corporate entities can also preserve resources and pursue projects that benefit future generations. During the 1950s and 1960s, it was common for large public corporations such as IBM, AT\&T, DuPont, Kodak, and Xerox to operate research laboratories devoted to pure science. These laboratories produced a wealth of inventions and innovations whose benefits we still enjoy, including the transistor, the laser, the solar cell, the ATM, the copying machine, and the digital camera. ${ }^{35}$ Today,

31. The Fabbrica was created in 1387 by the governor of Milan. The original administrative board included most of the notable Milanese authorities of the time, including the duke of Milan. Today the board has six members and a president. VENERANDA FABBRICA DEL DUOMO DI MiLANO, THE CHARTER OF VENERANDA FABBRICA (2013), available at http://www.duomomilano.it/en/infopage/the-charter-of-veneranda-fabbrica/7ec4fd2b-304e-4955987c-038b43da02c8/. Architects use the phrase "cathedral thinking" to describe projects that bring together the efforts of many different individuals over long periods of time to accomplish a socially beneficial objective that may not be realized until well into the future. Fareed Zakaria, 'Cathedral Thinking', Newsweek, Aug. 27, 2007, at 48. Put simply, this Symposium Article argues that the corporate form is a vital legal technology for promoting cathedral thinking.

32. Jennifer Thorpe, New College's Hall and Chapel Roofs (May 2008) (unpublished essay) (on file with author).

33. Id.

34. Although in some versions of this story the founder of New College planted the oak grove, a 2008 essay by the New College archivist states that the oak for the hall was harvested from woodlands acquired by the college seventy years after the hall was first built (but centuries before they were used for repairs). Id.

35. See generally DAVid C. MOWERy \& NATHAn Rosenberg, Paths of InNOvation: TECHNOlOGiCAL CHANGE IN 20TH CENTURY AMERICA (1999) (discussing the role of corporations, along with governments and universities, in fostering innovation in the United States). 
Google is pursuing pure research in robotics. ${ }^{36}$ While I may never benefit from the services of a personal robot, my children surely will.

The corporate form accordingly can serve, and historically has served, as a mechanism that allows present generations to preserve and invest resources to benefit future generations. ${ }^{37}$ To the extent that the people alive at any moment in time feel altruism toward the people they expect will follow them, the corporate form provides a vehicle to better express their generosity. ${ }^{38}$

\section{HOW PUBLIC BUSINESS CORPORATIONS CAN SHIFT WEALTH FROM THE FUTURE TO THE PRESENT}

\section{A. Present Generations Lack Sufficient Incentive to Invest Efficiently for Future Generations}

Unfortunately, while members of the present generation can use corporate entities to preserve and invest resources to benefit future generations, this does not mean they will. After all, why should they? They bear the cost, while the benefits will be enjoyed by others not yet born, who cannot even say "thank you."

The decision to commit resources to a nonprofit corporation to preserve and invest for future generations requires altruism. As I have ex-

36. See Jonathan Berr, Google Buys 8 Robotics Companies in 6 Months: Why?, CBSNEws.com (Dec. 16, 2013, 1:18 PM), http://www.cbsnews.com/news/google-buys-8-roboticscompanies-in-6-months-why/.

37. Another legal technology that permits present-day altruists to benefit future generations is the charitable trust. Although the tax advantages associated with creating a trust reduce the cost of altruism, they do not make it costless. In this regard, the public corporation with freely transferable shares may be a superior vehicle for promoting investment on behalf of future generations. See infra text accompanying note 53-59 (discussing how public corporations created incentives for the present generation to invest for the future).

38. Creating a corporation encourages altruism by reducing the risk an altruistic donor's contributions will be expropriated by others after the donor dies. Because the donor's contribution is locked into a legal entity controlled by a board whose members are precluded by the duty of loyalty from taking the entity's assets for themselves, the entity becomes more likely to pursue the cause for which it was created and less likely to be hijacked to serve the interests of some individual. However, other obstacles to collective altruism remain. For example, the availability of the corporate form does not solve the problem of free-riding altruists who prefer to rely on the donations of others.

Einer Elhauge has advanced the somewhat different argument that board governance encourages corporations to behave in a more altruistic and socially responsible fashion, because board members have better access than disbursed shareholders do to information about the corporation's social performance, and also are more easily targeted and shamed when corporations behave irresponsibly. See Einer Elhauge, Sacrificing Corporate Profits in the Public Interest, 80 N.Y.U. L. REV. 733 (2005). 
plored elsewhere, altruism is a real and common phenomenon. ${ }^{39}$ The human capacity for altruism appears limited, however. ${ }^{40}$ As an empirical matter, few individuals are selfless Mother Theresas willing to entirely subordinate their needs to serve others. As a result, even when the corporate form is available, the present generation likely will have only limited willingness to use it to lock away resources. This raises problems not only of intergenerational equity, but also of intergenerational efficiency.

To understand the efficiency problem, imagine a long-term project-say, devising a clean energy source or a means of dramatically extending the human lifespan - that requires a large investment now but may produce enormous returns decades or centuries hence. ${ }^{41}$ The expected gains from the project are so great that, even discounting future financial returns to present value and accounting for the possibility of failure, ${ }^{42}$ investing in the project is efficient. Unfortunately, mortal persons who cannot expect to live long enough to reap the benefits of investing in the project are unlikely to make the sacrifice necessary to pursue it.

For example, suppose that investing $\$ 100$ billion in research today would allow us to develop a technology for clean, cheap energy. Such a technology would benefit future generations for centuries to come. The expected future benefits of the research can be valued in trillions of dollars, even after discounting to present value and for risk of failure. In other words, the investment is efficient: its expected benefits substantially outweigh its costs. Nevertheless, the research is only likely to produce a commercially viable technology after forty years. This is well beyond the investing lifetime of most potential investors, as most people do not accumulate wealth to invest until middle age, and begin liquidating their

39. See generally Lynn Stout, Cultivating Conscience: How Good Laws MaKe Good People (2011).

40. Id.

41. As Nobel Prize-winning economist Robert Solow has famously argued, this sort of innovation and technological change is critical in driving economic growth. See generally Robert M. Solow, Technical Change and the Aggregate Production Function, 39 REV. ECON. \& STAT. 312 (1957).

42. Economists generally discount the value of future monetary benefits to reflect the time value of money (money received today has greater value than money that will be received in the future, because money received today can be invested to generate a return). However, experts debate whether nonmonetary benefits that will be enjoyed in the future should be discounted. For example, when choosing between adding to the life expectancy of someone who is alive today, and adding to the life expectancy of someone who will live one hundred years from now, it is not clear that life expectancy increases in the future should be assigned a lower value. See William Nordhous, The Stern Review on the Economics of Climate Change 6 (Nat'l Bureau of Econ. Research, Working Paper No. 12741, 2006), available at $\mathrm{http}: / / \mathrm{www}$. fordham.edu/economics/mcleod/nordhausonstern w12741.pdf (discussing this issue). 
investments when they retire in their sixties and seventies. Accordingly, such an investment might not be made.

Although the corporation provides a legal technology for pursuing economically desirable but long-term enterprises, the availability of this technology, alone, does not motivate present generations to pursue such enterprises. If the people currently living are less than perfectly altruistic - if they value their own welfare more than they value the welfare of those who will populate the planet after they die - present generations will invest for the future at suboptimal levels and fail to pursue many projects whose future benefits greatly outweigh their present costs. From an economic perspective, the resulting failure to invest for the future is inefficient. $^{43}$

\section{B. Now, Add Freely Transferable Shares and (Somewhat) Efficient Pricing}

Here is where a third characteristic commonly associated with certain types of corporations - in particular, with public business corporations of the sort described by Berle and Means in their 1932 treatise, The Modern Corporation and Private Property ${ }^{44}$ - comes into play. This third characteristic is the free transferability of shares.

Like asset lock-in and perpetual life, free transferability of shares is an important, if not necessarily universal, ${ }^{45}$ characteristic of business

43. Although economic theory is often associated with the celebration of selfishness, economics is a fundamentally communitarian philosophy that focuses on maximizing social welfare rather than the welfare of any individual. See DAVID W. BARNES \& LynN A. STOUT, CASES AND MATERIALS ON LAW AND ECONOMICS 11, 14-16 (1992) (discussing efficiency and social welfare). In maximizing social welfare, nothing in economic theory confines the inquiry to the present generation.

44. Adolf Berle \& Gardiner Means, The Modern Corporation And Private Property (1932).

45. Perpetual life and lock-in are not found in all corporations, because lock-in can be defeated by a controlling shareholder, and corporations can be chartered for limited periods or terminated by bankruptcy, merger, or dissolution. Similarly, two other characteristics associated with the corporate form, centralized management and limited liability for shareholders, are not universal. A corporation may have a controlling shareholder who manages the firm, and limited liability for shareholders can be waived by agreement - and in any case is a relatively new attribute of the corporate form. See Mark Weinstein, Limited Liability in California 1928-1931: It's the Lawyers, 7 AM. L. \& ECON. REV. 439 (2005) (limited shareholder liability was not a feature of California corporations until well into the twentieth century, and when added by statute did not appear to affect the market price of California firms).

For present purposes, centralized professional management and limited shareholder liability are important corporate characteristics primarily because they support asset lock in and free transferability of shares. A corporation managed by a controlling shareholder lacks asset lock-in, and limited liability for shareholders encourages free transferability of shares. If shareholders were personally liable for the corporation's acts, it would be much more difficult to develop an active market for 
corporations. Partnerships not only lack asset lock-in and perpetual life, they also lack free transferability: the default rule is that a partner cannot sell or transfer his or her interest in a partnership. Instead, when a partner dies or withdraws, the partnership is terminated. ${ }^{46}$ But shareholders in corporations typically can sell their shares to buyers who enjoy all the legal rights to vote and to receive dividends enjoyed by the original shareholder. ${ }^{47}$

This means that, even though a shareholder in a corporation is not entitled to extract any of the corporation's assets directly from the corporation, she nevertheless may be able to convert her financial interest in the company into cash by selling her shares to a new shareholder. Although corporate assets are fixed and locked in, investor interests in corporate shares can be relatively liquid. This liquidity finds its most perfect expression in the case of shares of a large public corporation subject to effective antifraud and disclosure rules that are listed for trading on an organized, well-developed exchange. The market for shares of such corporations is typically, to at least some degree, "fundamental value efficient." 48

Economists use the concept of fundamental value efficiency, which plays a critical role in our analysis, to describe a market in which share prices reflect the future expected economic returns (dividends and share price appreciation) associated with owning the shares. ${ }^{49}$ There are a number of reasons to suspect most stock markets are not perfectly fundamental value efficient. For example, investors do not always have easy access to the information they need to value shares, they do not always

shares, as potential buyers would want to have extensive information not only about the company itself but about the wealth and creditworthiness of other shareholders. FRANK H. EASTERBROOK \& DANIEL R. FisCHEL, THE ECONOMIC STRUCTURE OF CORPORATE LAW 41-43 (1991).

46. See UNIF. P'SHIP ACT $\S 31$ (1914).

47. It can remain difficult as a practical matter to sell shares in a private corporation that is not traded on a well-developed exchange, and it is also not unusual for such companies to impose restrictions on the sale of shares to third parties. Thus, in private companies, altruism toward future generations of shareholders may be the primary motivation for present-generation shareholders to make very long-term investments.

48. See generally Ronald J. Gilson \& Reinier H. Kraakman, The Mechanisms of Market Efficiency, 70 VA. L. REV. 549, 560-61 (1984) (discussing market efficiency). Fundamental value efficiency should be distinguished from informational efficiency. A market is said to be informationally efficient when it is difficult to make a profit by trading on newly acquired information, because market prices have already responded to that information. However, informational efficiency alone does not imply that prices that respond quickly to information also necessarily provide an accurate measure of fundamental economic value. Id. at 554-65 (distinguishing informational efficiency from fundamental value efficiency).

49. See generally Lynn A. Stout, The Mechanisms of Market Inefficiency: An Introduction to the New Finance, 28 J. CORP. L. 635 (2003). 
agree on how to interpret that information, and they may not always interpret information rationally. ${ }^{50}$ Nevertheless, most experts believe that the market for shares of large, publicly traded corporations subject to antifraud and mandatory disclosure rules is to some degree fundamental value efficient. ${ }^{51}$ As Nobel Prize-winning economist Fischer Black once put it, modern stock markets are likely "efficient by a factor of 2," so that "price is more than half of value and less than twice value."

To the extent the stock market is even somewhat fundamental value efficient, the possibility arises that mortal human beings can use publicly traded, for-profit corporations to transfer wealth not only from present generations to future generations, but also from future generations to present generations. The corporation now can transport wealth in both temporal directions.

\section{Transforming Future Returns into Present-Day Wealth}

To understand this point, consider the perspective of a shareholder in a corporation that is pursuing some long-term project (say, mining the asteroid belt) unlikely to produce profits during the shareholder's remaining investing lifetime. If the shareholder cannot sell her shares, she will attach no value to corporate profits likely to be earned only after she has died or otherwise transferred share ownership.

But in a reasonably liquid and fundamental value efficient market, the shareholder can sell her shares to a younger shareholder who places a positive value on the future profits, because the younger shareholder expects to own the shares when the profits appear. Similarly, the younger shareholder might value future profits likely to be earned after he has transferred ownership, if he too anticipates he can sell his shares to an even younger investor who will own the shares when profits finally start rolling in.

And so on, ad infinitum. Through the vehicle of a public corporation whose shares are traded at prices reflecting future returns, profits earned in the distant future can be transformed into wealth that can be enjoyed today. For example, if Google's decision to invest in self-driving cars increases today's price for Google stock, the present generation of Google shareholders can hope to profit from Google's investment even if

50. $I d$. at 649,660 .

51. The U.S. Supreme Court recently subscribed to this view. See Halliburton Co. v. Erica P. John Fund, 134 S.Ct. 2398, 2410 (2014) ("[M]arket efficiency is a matter of degree." (citing Basic Inc. v. Levinson, 485 U.S. 224 (1988))).

52. Fischer Black, Noise, 41 J. Fin. 529, 533 (1986). 
they do not expect to own Google shares when the technology becomes commercially viable.

This transformation of future expected returns into present-day wealth occurs to some extent even if equity markets are "noisy" and prices do not perfectly capture expected future returns. ${ }^{53}$ A rough correlation between price and value can still allow a present generation of shareholders to capture much of the benefit of investing for the future. For example, whether the market calculates the future benefits of selfdriving cars at $\$ 1$ trillion or $\$ 2$ trillion, the project remains attractive if the initial investment required is a mere $\$ 100$ billion. The public business corporation's capacity to transform future profits into current share prices does not need to be perfect for business corporations to perform the function of shifting wealth backwards in time. ${ }^{54}$

\section{Public Corporations Permit Efficient Intertemporal Exchange}

This means that, once we create a corporation with asset lock-in, perpetual life, and freely transferable shares traded in a reasonably efficient market, we have created an institution that can operate as a fullyfunctioning "wormhole" in time. Not only can the corporation convert present wealth today into future profits that benefit future shareholders, it can also transform those future profits into wealth that can be enjoyed by present shareholders today, in the form of a higher share price.

The corporate form accordingly allows a type of implicit exchange between different cohorts of human beings. A present generation that might otherwise decline to make efficient investments that benefit future generations becomes more willing to do so because the present generation is immediately compensated when expected future profits raise share price. This clearly benefits the current generation. And, to the extent the present generation of shareholders does not capture all the gains from this intergenerational "trade" - perhaps because stock price does not capture all future profits, or because the project will provide external benefits to nonshareholders like employees, customers, or tax-collecting governments - future generations of shareholders and nonshareholders benefit as well.

53. Id. at 529-30.

54. A noisy correlation between price and value does create the risk that, if the present generation of shareholders has the ability to unlock capital and extract assets from the corporation, they will choose to exercise this ability in ways that defeat the corporation's ability to transfer resources into and make investments for future generations. See infra note 102 and accompanying text (discussing this risk). 
The mechanism is unlikely to work perfectly. After all, the future is uncertain. Projects that are economically desirable from an efficiency perspective may not be pursued because the present generation of shareholders does not expect all future benefits to be fully incorporated into today's share price. ${ }^{55}$ Alternatively, if the market overvalues a project, a wasteful investment might be made that does not pan out. ${ }^{56}$

Nonetheless, however imperfectly business corporations perform their time-shifting function, having a dull knife is better than having no knife at all. With even a flawed ability to transfer wealth backward in time as well as forward, the public business corporation can help overcome the limits of human altruism that otherwise cause present generations to systematically underinvest in the future. No longer must those who will follow us depend only on the charity of those who walk the planet today. The public corporation harnesses the self-interest of the living to serve the interests of those not yet born. In doing so, it benefits both groups, allowing present and future generations to participate in a mutually beneficial intertemporal exchange of wealth that promotes both intergenerational efficiency and intergenerational equity.

Of course, given the realities of risk and uncertainty, and the need to discount future financial returns (if not future well-being) ${ }^{57}$ to present value, intertemporal exchange may only be efficient for relatively rare, long-term projects where present day investment will eventually produce much larger future benefits. Such projects may be few and far between. Yet as Nobel Prize-winning economist Robert Solow has demonstrated, they may also be disproportionately important to human progress and prosperity. ${ }^{58}$ History offers many examples of transformational technologies - railroads, electric lighting, antibiotics, contraceptive pills, the transistor, the desktop computer - that required decades to develop and adapt for commercial use, yet have since provided so many benefits to multiple generations that from a social perspective they have paid for their initial investment costs many times over. Only a little imagination is needed to think of similar enterprises we might pursue today: extending the human lifespan, developing algal biofuels, mining the asteroid belt. Business corporations with asset lock-in, perpetual life, and efficiently traded shares help overcome the limits to altruism that prevent us from pursuing

55. See infra Part IV.F (discussing market undervaluation).

56. See infra text accompanying notes 100-01 (discussing market overvaluation).

57. See supra note 42 (discussing whether future nonmonetary benefits should be discounted).

58. See Solow, supra note 41. 
such ideas. ${ }^{59}$ However imperfectly, the public corporation helps human beings address at least some of the equity and efficiency problems associated with their own mortality.

\section{E. A Note on the Problem of Agency Costs}

Many readers may find the notion of corporate entities as vehicles for transferring wealth between generations jarringly at odds with the contemporary literature on the nature and purpose of corporations. In part, this may be because academics share the natural human tendency to pay attention mostly to the interests of the living. But it is also because most contemporary corporate scholarship focuses on a problem orthogonal to intergenerational equity and efficiency. This is the problem of manager-imposed agency costs. ${ }^{60}$

Corporate entities are real entities that exercise real influence. ${ }^{61}$ But they exercise influence through human agents. Given the weaknesses of human nature, it is only to be expected that corporate agents - in particular, corporate directors and executives - sometimes seek to serve their own interests rather than the entity's objectives. ${ }^{62}$ Modern corporate scholarship focuses rather obsessively on this managerial "agency cost" problem. ${ }^{63}$ Indeed, a casual reader could be forgiven for concluding that the only problem posed by corporate entities is the challenge of eliminating the waste that results when corporate managers fail to run firms in an optimal fashion (usually assumed to be a profit-maximizing fashion). ${ }^{64}$

59. In fact, present-day corporations are pursuing each of these projects. Human Longevity, Inc. is seeking to combat aging. See HUMAN LONGEVITY INC., http://www.humanlongevity.com (last visited Oct. 3, 2014). Synthetics Genomics is developing commercial algal biofuels. See SYNTHETIC GENOMICS, http://www.syntheticgenomics.com (last visited Oct. 3, 2014). And Planetary Resources' stated goal is asteroid exploration and mining. See Planetary Resources, http://www.planetaryresources.com (last visited Oct. 3, 2014).

60. Edward B. Rock, Adapting to the New Shareholder-Centric Reality, 161 U. PA. L. REV. 1908, 1913-17 (2013) (discussing "classic agency cost analysis"); see also Michael C. Jensen \& William H. Meckling, Theory of the Firm: Managerial Behavior, Agency Costs and Ownership Structure, 3 J. FIN. ECON. 305 (1976) (the most frequently cited article in the managerial literature); Roger L. Martin, Fixing the Game: Bubbles, Crashes, And What Capitalism CAN Learn FROM THE NFL 11 (2011).

61. Even thoughtful observers sometimes describe corporations as "legal fictions." Any good lawyer knows this phrase is an oxymoron. There is nothing fictional about legal institutions, which exercise enormous influence over human beings. That corporations are invisible does not make them fictional or unreal. Gravity, too, is invisible.

62. People asked to act as agents or fiduciaries tend to misbehave in one of two ways: they act either foolishly or knavishly. The fiduciary duty of care addresses the first possibility; the duty of loyalty addresses the second.

63. See Rock, supra note 60, at 1909 (describing how agency costs have been viewed as "the central problem of U.S. corporate law").

64. See id. at 1911-17 (describing the "classic" shareholder-manager agency cost "paradigm"). 
To someone who believes controlling manager-imposed agency costs is the first and perhaps only policy priority in regulating corporate entities, the idea of using business corporations to lock in wealth and transfer it between generations may seem unwise. This is because corporate entities (including not only business corporations, which Blair and I discuss at length in our 1999 article, but also nonprofits) typically achieve lock-in by placing control of the entity's assets in the hands of a board whose members are prohibited by the duty of loyalty from taking the assets for themselves. ${ }^{65}$ Yet simply precluding directors from using their corporate powers to enrich themselves does not leave them with strong incentives to serve the corporation's interests. ${ }^{66}$ Directors protected by the business judgment rule have ample room to shirk by devoting inadequate time and attention to the corporate entity. ${ }^{67}$ Accordingly, public corporations governed by boards risk seeing their resources frittered away. The only way to avoid such waste (or so the agency cost argument typically goes) is to make directors "accountable" by making it easier for shareholders to replace poorly performing boards, or tying director or executive pay to some metric of shareholder returns. ${ }^{68}$

At the outset, it is worth noting there seems no logical reason to assume corporate assets paid out to directors, employees, or governments in the form of fees, salaries, or taxes are somehow "wasted," while corporate assets paid out to shareholders in the form of dividends or share repurchases are not. ${ }^{69}$ More important for present purposes, however, is

65. See Blair \& Stout, supra note 5, at 306. Although corporate law makes it difficult for directors to extract wealth from the corporation for themselves or their families, it is less effective at preventing directors from using their powers to benefit friends or favorite employees (for example, a popular CEO). This is another and perhaps inevitable source of managerial agency costs.

66. Id. The primary motivation for directors to do their best to serve corporate entities may be some combination of the desire to keep the entity healthy so they can keep their board positions; the desire to maintain and build their own status and reputations as business leaders; and the altruistic desire to benefit the executives, employees, customers, and shareholders to whom they may feel a sense of obligation. History has proven that this imperfect set of incentives can be sufficient to allow board-controlled nonprofit and for-profit corporate entities to survive and thrive for decades and even centuries, and play major roles in the global economy.

67. See Lynn A. Stout, On the Proper Motives of Corporate Directors (Or, Why You Don't Want to Invite Homo Economicus to Join Your Board), 28 DEL. J. CORP. L. 1, 6-9 (2003) (discussing effects of business judgment rule).

68. See, e.g., Lucian Bebchuk \& Jesse Fried, Pay Without Performance: The UNFULFILLED PROMISE OF EXECUTIVE COMPENSATION (2004) (arguing that executive pay should be tied to shareholder returns); Lucian Bebchuk, The Myth of the Shareholder Franchise, 93 VA. L. REV. 675, 700-01 (2007) (arguing that shareholders should have more power to remove boards).

69. As David Ciepley has pointed out, any sophisticated discussion of agency costs in the corporate context must address the question of who, exactly, is the principal and who is the agent. See David Ciepley, The Corporation is Always Already Government-Supported, and So Is Bankruptcy, 11 Geo. J.L. \& PUB. POL’y 349, 367-69 (2013). Although modern scholars sometimes assume 
that asking managers to focus only on the interests of the current generation of shareholders may be a corporate cure far worse than the agency cost disease. As discussed further below, if present-day shareholders are given too much influence over corporate policies relating to distributions of corporate assets, it can become difficult or impossible for corporations to pursue long-term goals. Trying too hard to eliminate managerial agency costs can render public corporations unable to perform their most critical economic function. ${ }^{70}$

The dilemma is similar to the quandary posed by light bulbs. Even LED light bulbs waste enormous energy, with as much as $85 \%$ converted to undesirable heat rather than light. ${ }^{71}$ If eliminating waste were our only concern, we would turn off all light bulbs. But then we would be left to sit in darkness. Similarly, a certain level of agency costs, possibly a very high level, may be the price we must pay to reap the benefits of longterm corporate investment.

This does not mean every enterprise requires a corporation. For short-term projects promising modest benefits, the managerial agency costs associated with using a public business corporation may be too great to be worthwhile. Such projects should be pursued using other business forms, like a partnership, or a corporation with a controlling shareholder. ${ }^{72}$ But for large enterprises that must operate for long periods of time in uncertain conditions to achieve potentially enormous benefits, a high level of agency costs becomes acceptable. IBM and AT\&T likely

shareholders are the principals in the corporation, this erroneous presumption ignores the significance of legal personhood. See STOUT, supra note 21, at 42-44 (discussing why shareholders are not principals). Legal personhood explains why directors and executives owe fiduciary duties not only to shareholders and sometimes creditors, but to the corporate entity itself. Blair \& Stout, supra note 5, at 296 (discussing to whom fiduciary duties are owed). This perspective suggests that managers who respond to shareholder pressure by disgorging corporate assets to current shareholders in a fashion that interferes with the entity's long-term survival are imposing a kind of agency cost on the corporate entity. See Schwartz, supra note 26, at 822-23 (making this argument). Future shareholders and possibly future stakeholders may also be burdened. $I d$. Conversely, the managerial "empire building" many scholars view as an agency cost may be in the interests of the corporate entity and of future generations, even if it is not always in the interests of the current generation of shareholders.

70. See infra Part IV (discussing this problem).

71. Fact or Fiction-LEDs Don't Produce Heat, LEDs MAGAZINE (May 2005), http://www.ledsmagazine.com/articles/2005/05/fact-or-fiction-leds-don-t-produce-heat.html. Only $15 \%$ of the energy consumed by a typical LED bulb is used for visible light. Id. Incandescent bulbs do much worse, converting only $5 \%$ of the energy used to light. $I d$.

72. Because they lack effective lock-in, corporations with controlling shareholders will likely function well as vehicles for shifting wealth forward through time only when their controlling shareholder is altruistic toward future generations. Even in such cases, there remains the problem of ensuring that future controlling shareholders continue the altruistic, future-oriented plans of the original controlling shareholder. See infra notes 119, 121, and accompanying text (discussing this problem). 
incurred very high levels of "wasteful" agency costs while operating their Big Blue and Bell Labs research divisions during the 1950s and 1960s. Nevertheless, those costs have been repaid many times over by the gains to multiple generations of shareholders (and others) from developing the computer and the transistor. Similarly, multiple future generations may benefit enormously from current corporate projects to develop self-driving cars, commercial space transport, and algal biofuels. ${ }^{73}$

\section{THE DESTRUCTIVE IMPACT OF SHAREHOLDER VALUE THINKING}

\section{A. Corporate Entities and Shareholder Primacy}

Parts II and III of this Symposium Article have suggested that corporations can be understood as immortal entities that pursue long-term, open-ended projects that benefit multiple human generations. This perspective on the corporate form might feel familiar to an American CEO in the twentieth century (or a bishop in the Middle Ages). Yet it may look foreign to contemporary readers. This is because, for the past two or three decades, most business experts have embraced a quite different theory of the business corporation sometimes called shareholder primacy. $^{74}$

Shareholder primacists typically view corporations not as entities but as the property of the current generation of human beings who hold their shares. ${ }^{75}$ Because these present-day shareholders "own" the corporation, it is they - and not the company's board of directors - who deserve the final say on how corporate assets are used. The board is not viewed as an independent body but as the agent of today's shareholders, who tolerate board governance only to save themselves the bother of ex-

73. See, e.g., Clay Dillow, An Aggressive SpaceX Puts Commercial Space Rivals on Notice, FORTUNE (Aug. 26, 2014), http://fortune.com/2014/08/26/an-aggressive-spacex-puts-commercialspace-rivals-on-notice/; Michael Humphrey, Google Self-Driving Cars and All Tech: Are You Ready to Give Up the Wheel?, FORBES (Aug. 25, 2014), http://www.forbes.com/sites/michaelhumphrey/

2014/08/25/google-self-driving-cars-and-all-tech-are-you-ready-to-give-up-the-wheel/; Antonio Regalado, Three Questions for J. Craig Venter, MIT TECH. REV. (July 30, 2014), http://www.techno logyreview.com/news/529601/three-questions-for-j-craig-venter/. Interestingly, each of these corporations has found a way to protect itself from shareholder demands to unlock corporate assets. Google has a dual class structure that disenfranchises its public shareholders, while SpaceX is privately owned by Elon Musk and Synthetic Genomics by Craig Venter.

74. For a fuller discussion of shareholder primacy's influence, see Henry Hansmann \& Reinier Kraakman, The End of History for Corporate Law, 89 GEO. L.J. 439, 449-51 (2001).

75. STOUT, supra note 21 , at 37-38. The phrase "shareholder primacy" is misleading. Shareholder primacy not only privileges shareholders' interests, but discounts all others'; "shareholder absolutism" is a more accurate label. Moreover, shareholder primacy focuses on the interests of the current generation of shareholders to the exclusion of future shareholders. 
pending their own time and energy on corporate affairs. ${ }^{76}$ In keeping with the homo economicus model of neoclassical economic theory, shareholders are assumed to want only more wealth. And in keeping with the theory of efficient stock markets, today's share price is assumed to be the most accurate measure of shareholder wealth.

Accordingly, shareholder primacy theory counsels that managers ought to relentlessly "maximize shareholder value." As a practical matter, this translates to focusing on maximizing dividends and share price appreciation, to the exclusion of other corporate concerns.

How does this business philosophy mesh with the idea of the corporation as a vehicle for the efficient intertemporal exchange of wealth between generations? The remainder of this Symposium Article explores this question. As we shall see, if equity markets are perfectly fundamental value efficient, so that share prices accurately reflect the expected future economic returns to holding shares, "maximizing shareholder value" does not necessarily threaten the corporate entity's capacity to efficiently preserve and invest resources for future generations. But if - as seems far more likely—stock markets are only somewhat efficient, taking a shareholder-centric ${ }^{77}$ approach to corporate governance (the shareholder in question being today's shareholder, not tomorrow's) may undermine one of the most vital economic functions that business corporations perform.

\section{B. The Rise of the American Public Corporation}

Western law has provided for corporate entities with asset lock-in and perpetual life since at least the Middle Ages. ${ }^{78}$ However, the publicly traded business corporation is a relatively new invention that became common in the United States after the turn of twentieth century. Its arrival on the economic scene was famously described by Adolf Berle and Gardiner Means in their classic 1932 work, The Modern Corporation and Private Property. ${ }^{79}$ Berle and Means documented how gigantic, ex-

76. This view has been especially pressed by Stephen Bainbridge, who holds that corporations ought to be run to maximize shareholder value but also argues that the best means to this end is to insulate boards from shareholder control because shareholders are not in a good position to act collectively or to know their own best interests. See Stephen M. Bainbridge, The Case for Limited Shareholder Voting Rights, 53 UCLA L. REV. 601, 608-12 (2006). Bainbridge fails to explain why corporate law does not allow shareholders to reclaim control over corporate decision making in cases where the costs of becoming informed are extremely low and collective action is easy (for example, voting whether to accept a buyout at a premium price).

77. I owe this useful phrase to Edward Rock. See Rock, supra note 60.

78. Ciepley explores still older, Roman origins. See Ciepley, supra note 28, at 7.

79. See BERLE \& MEANS, supra note 44. 
change-traded companies had come to dominate the U.S. economy. They also pointed out how the widely dispersed shareholders in such companies faced collective action obstacles that left them nearly powerless to use their already limited voting rights effectively. Authority over these powerful new public corporations rested in the hands of a professional class of executives and directors remarkably insulated from outside control. $^{80}$

Managerial control kept public companies' assets firmly locked in. Shareholders who were powerless to demand dividends or share repurchases, and who wanted to convert their interests in public companies into cash, had but one realistic option: sell the shares to someone else. Luckily, selling shares had become relatively easy thanks to the rise of the New York Stock Exchange (NYSE). The passage of the Securities Act of 1934, with its disclosure and antifraud rules, also made it more likely shareholders could receive a decent price for their shares. ${ }^{81}$ Thus the emergence of a highly liquid and reasonably fundamental value efficient secondary market meant that shareholders who wanted an immediate return on their investment had less need for dividends or share repurchase programs.

The twentieth century accordingly ushered in conditions highly favorable for creating business corporations that could not only shift wealth forward in time, but also convert expected future wealth into a higher share price today. As anticipated in Part III, this arrangement allowed public corporations to undertake large-scale investment projects over long periods of time under highly uncertain conditions. Firms like IBM, GE, U.S. Steel, Kodak, Xerox, DuPont, and AT\&T embarked on intensive long-term research and development programs that eventually produced groundbreaking innovations - the transistor, the desktop computer, digital cameras - that often entered widespread commercial use only after decades of work. These innovations have since provided incalculable benefits to both shareholders and society. For example, this Symposium Article was written using voice recognition software, a po-

80. Berle and Means famously described public companies as having a "separation of ownership and control." As Blair and I have pointed out, this phrase is misleading. Shareholders do not own corporate entities but only own equity shares, which are a kind of contract between the shareholder and the corporate entity. Blair \& Stout, supra note 5, at 274 n.57. As legal entities, corporations "own" themselves. STOUT, supra note 21, at 38.

81. In the absence of effective antifraud rules, buyers discount the value of goods offered for sale, depressing prices. See George Akerlof, The Market for Lemons: Qualitative Uncertainty and the Market Mechanism, in UNCERTAINTY IN ECONOMICS: READINGS AND EXERCISES 235 (Peter Diamond \& Michael Rothschild eds., 1989). 
tentially transformative technology that IBM began working on in the 1960 s but that only recently has become commercially viable. ${ }^{82}$

Notably, the dominant business philosophy of twentieth-century public companies was not shareholder primacy but "managerial capitalism," or more simply, "managerialism." 83 Managerialist directors and executives did not view themselves as servants of the company's current shareholders. Rather, they saw themselves as trustees or stewards of great economic institutions that had important public functions. ${ }^{84}$ These functions included not only providing returns to equity investors, but also serving the needs of customers, employees, suppliers, creditors, and the nation as a whole. In serving these interests, managers were free to focus their attention not only on the present generation, but on future generations as well. Managerialism allowed public companies to be run with a forward-looking focus that led to a wide variety of technological breakthroughs we still benefit from enormously today.

\section{Shareholder Value Thinking Arrives}

Toward the end of the twentieth century, however, American public companies began to change. The shift began in academia with the rise of the Chicago School of free market economists. ${ }^{85}$ Influential economic thinkers like Milton Friedman and Michael Jensen, apparently viewing the public corporation rather like a gigantic sole proprietorship, argued that the absence of shareholder power in public companies noted by Berle and Means was a problem to be solved rather than a deliberate legal strategy to achieve asset lock-in. ${ }^{86}$ They erroneously described shareholders as the "owners" and sole residual claimants of corporations. ${ }^{87}$ They further assumed that shareholders wanted only to maximize

82. See Pioneering Speech Recognition, IBM, http://www03.ibm.com/ibm/history/ibm100/ us/en/icons/speechreco/transform/ (last visited Aug. 28, 2014).

83. See Gerald F. DAvis, MANAGEd by the MARKets: How FinANCE RE-Shaped AmericA 72-77 (2009) (discussing managerialist era).

84. Id. at 74-75.

85. See generally Steven M. Teles, The Rise of the Conservative Legal Movement: THE BATTLE FOR CONTROL OF THE LAW 216 (2008) (describing the influence of free market economists on the legal system).

86. StouT, supra note 21 , at 18 . Berle and Means themselves did not share the view that the separation of share ownership from control needed to be remedied. Lynn A. Stout, On the Rise of Shareholder Primacy, Signs of its Fall, and the Return of Managerialism (In the Closet), 36 SEATTLE U. L. REV. 1169, 1170-71 (2013).

87. Rather than owning corporations, shareholders own shares, which are a contract with the corporate entity. Similarly, the corporate entity is its own residual claimant. STOUT, supra note 21 , at 37-41. While the idea of shareholder "ownership" of the firm might be forgiven as a convenient and harmless metaphor when describing a company with a controlling shareholder, it is grossly misleading when applied to a board-controlled company. 
"shareholder value," usually treated as synonymous with maximizing dividends plus share price appreciation. ${ }^{88}$

This theoretical approach to understanding corporate entities led many influential thinkers in the 1970 s and 1980 s to conclude that corporate projects that did not generate obvious and immediate financial returns must be inefficient "empire building." ${ }^{\text {" }} 99$ Shareholder powerlessness in managerial firms was viewed as further evidence American corporations were broken and needed to be fixed. ${ }^{90}$ Although remarkably little hard data supported these claims, ${ }^{91}$ they were eagerly embraced by a rising generation of academics. They also appealed to a more powerful interest group: the pension funds, mutual funds, and hedge funds that had begun to dominate the stock market by the 1990s. Unlike disbursed and passive retail investors, these institutional shareholders were large enough to make meaningful attempts to influence board decisions, and they saw opportunities to profit by pressuring boards to shift corporate policy toward shareholder primacy. ${ }^{92}$

Shareholder primacy thinking began to influence federal law. In 1992, for example, the U.S. Securities and Exchange Commission (SEC) amended its proxy rules to promote "shareholder democracy" by giving

88. See generally Hansmann \& Kraakman, supra note 74. As I have pointed out elsewhere, this assumption is tantamount to assuming that shareholders act like psychopaths who are indifferent to the consequences that their investing decisions impose on others. STOUT, supra note 21, at 95-102.

89. See Rock, supra note 60, at 1915 (describing perceived problem of empire building).

90. See, e.g., Bebchuk, supra note 68 (describing supposed problem of shareholder powerlessness). Ironically, while the idea that legislative intervention and central planning by academics can produce better corporate governance rules than private contract and common law is associated with economic analysis of corporate law, it is inconsistent with the Hayekian approach that the free market economists who sparked the movement favored. Stout, supra note 86, at 1181.

91. Rock, supra note 60, at 121-22 (discussing empirical evidence); STOUT, supra note 21, at 34-47 (same); Lynn A. Stout, The Toxic Side Effects of Shareholder Primacy, 161 U. PA. L. REV. 2003, 2008 (2013) (same). The conventional wisdom that managerialist companies perform poorly has little empirical support. Academics typically rely on the well-documented phenomenon that, when a target company is sold or a conglomerate is broken up into several individual firms, share price rises. However, this price rise is not accompanied by any evidence of improved operating performance and is likely the result of the "winner's curse" commonly seen in auctions. Stout, supra.

Among laymen, shareholder primacy acquired emotional appeal in the $1980 \mathrm{~s}$ as a result of a severe bear market in the 1970s, along with the decline of the U.S. auto and steel industries. However, the 1970s bear market was primarily due to the Arab oil embargo, which quadrupled the price of oil. Stout, supra note 86, at 1172-75, 1178-81 (discussing 1970s bear market). Similarly, while the struggles of the U.S. auto and steel industries are often cited as anecdotal evidence of the failures of managerialism, this explanation seems weak because managerialist firms dominated the U.S. economy for decades before the auto and steel industries ran into trouble. A better explanation may be the rise of too-powerful labor unions in those industries that were able to unlock corporate assets for their own benefit. See supra notes 18-19 (discussing problem of stakeholders unlocking corporate assets).

92. Rock, supra note 60, at 1922-23. 
shareholders greater freedom to coordinate proxy campaigns, opening the door for the emergence of the activist hedge fund. ${ }^{93}$ An even more important change came in 1993, when Congress amended the tax code to require companies to tie top executives' pay to objective performance measures in order to gain full tax deductibility. ${ }^{94}$ In keeping with shareholder value thinking, share price became the popular metric and stock options the favorite form of compensation, with the eventual result that CEOs now have most of their income and personal wealth tied to share price performance. ${ }^{95}$ Meanwhile, activist investors and other shareholder privacy advocates pushed companies to adopt governance practices that made boards more sensitive to shareholder demands, such as majority voting rules in director elections and "destaggered" board structures. ${ }^{96}$

Such changes in law and practice ensured that, by the close of the twentieth century, shareholder value thinking had replaced managerialism as the dominant business philosophy in public corporations. In the words of influential corporate scholar Edward Rock: "Managers now largely think and act like shareholders." read "today's shareholders, who care only about their own material wealth.") Directors and executives now often run public companies with a single goal in mind: maximizing shareholder value.

\section{Shareholder Value Thinking with Perfectly Efficient Markets}

How has the shift from managerialism to shareholder primacy affected the public corporation's ability to efficiently transfer wealth back

93. See Iman Anabtawi \& Lynn Stout, Fiduciary Duties for Activist Shareholders, 60 STAN. L. REV. 1255, 1274-83 (2008) (discussing this and other legal changes that have empowered institutional shareholders).

94. Stout, supra note 86 , at 1176 (discussing tax code change).

95. Rock, supra note 60, at 1924.

96. A classic example of the influence of shareholder value thinking on corporate practice is the modern practice of "destaggering" corporate boards so that companies become more vulnerable to hostile takeover bids. This trend did not emerge organically from the business world but was driven by an academic policy initiative associated with a law professor, Lucian Bebchuk. See Steven Davidoff Solomon, The Case Against Staggered Boards, N.Y. TIMES (Mar. 20, 2012), http://dealbook.nytimes.com/2012/03/20/the-case-against-staggered-boards (describing trend toward destaggering and role of Harvard governance project). A second outside force that has pushed companies to destagger their boards is Institutional Shareholder Services (ISS), a company that advises mutual and pension funds how to vote the shares in their portfolios. Id. ISS is notorious both for its lack of accountability and for the lack of empirical evidence to back up its recommendations. See generally Tamara Belinfanti, The Proxy Advisory and Corporate Governance Industry: The Case for Increased Oversight and Control, 14 STAN. J.L. BUS. \& FIN. 384 (2009) (critiquing ISS); see also Robert M. Daines et al., Rating the Ratings: How Good are Commercial Governance Ratings?, 98 J. FIN. ECON. 439 (2010) (same).

97. Rock, supra note 60, at 1988. 
and forth between different generations of shareholders? To address this question, let us start by assuming, rather unrealistically, that stock markets are perfectly fundamental value efficient. In other words, assume today's stock price always perfectly captures the discounted present value of all future economic returns not only to the company's current generation of shareholders, but to all its future shareholders as well.

As explored earlier, perfectly fundamental value efficient stock markets fully compensate current shareholders for corporate investments that eventually produce returns exceeding their costs - even if those returns come after today's shareholders have died or sold their shares. Thus efficient stock markets give today's shareholders incentives to support efficient corporate investment in the future. A corollary is that giving today's shareholders more power over boards of directors, or tying executive pay to shareholder returns, becomes less likely to harm the public company's ability to serve future generations. ${ }^{98}$ By tempering agency costs, it may even help.

But as already noted, it is unrealistic to assume stock markets are always perfectly fundamental value efficient. What happens if markets are only sometimes, or only somewhat, efficient? What is the result if, as seems highly likely, share prices occasionally undervalue or overvalue future returns? ${ }^{99}$

\section{E. Shareholder Value Thinking with Imperfectly Efficient Markets}

When stock markets are imperfectly efficient, shareholder primacy's tenets that shareholders need power over boards, and that managers need incentive to maximize shareholder value, begin to cause problems. Those problems, moreover, are asymmetrical: a market that undervalues a company's stock is likely to produce more negative efficiency consequences than a market that overvalues that stock.

To see why, imagine there is an inefficient bubble for a company's stock - the price for shares exceeds the value of likely future returns from dividends and share price appreciation. Such overvaluation can result in the misallocation of resources when the company issues new shares to investors because the funds the company raises would be better

98. Perfectly fundamental value efficient markets still do not solve the problem of corporate externalities, or the possibility of ex post shareholder opportunism that Blair and I explored in $A$ Team Production Theory of Corporate Law. See supra note 5. It should also be noted that tying executive pay to shareholder returns does not necessarily serve shareholders' pro-social interests. See StOUT, supra note 21, at 96-101 (discussing the likelihood that nonpsychopathic shareholders care about more than financial performance).

99. See supra text accompanying note 48 (discussing market inefficiency). 
invested elsewhere. But because corporations issue new equity so rarely, misallocations in the primary market are unlikely to be a serious economic problem. ${ }^{100}$ Most of the time, stock overpricing only affects secondary market trading, causing investors purchasing shares to transfer some of their wealth unnecessarily to investors selling shares. This redistributes wealth among investors, but does not systemically misallocate resources. $^{101}$

The situation is more troubling when the market undervalues companies. Like overpricing, underpricing in the primary market for shares misallocates resources (although instead of investors' funds being wasted on less desirable corporate projects, now good projects go begging). But again, corporations rarely use the primary market. The greater economic problem is underpricing in the secondary market. Unlike secondary market overpricing, which mostly just transfers wealth, secondary market underpricing threatens serious resource allocations. This is because, as explored below, secondary market underpricing can give a corporation's current shareholders reason to try to unlock corporate assets that efficiency demands should stay committed to long-term corporate projects.

\section{F. Cutting Corporate Oaks}

To understand the perverse incentives secondary market underpricing creates for shareholders to unlock corporate assets, consider the dilemma a shareholder faces when the stock market undervalues her shares. The shareholder may believe the market will eventually come to correctly price the company's stock. But when? The market may not correct itself until after she has sold her shares. This is especially likely in today's world of low trading costs and high turnover, where the average holding period for shares listed on U.S. exchanges is only four months. ${ }^{102}$

In periods of market undervaluation, it may no longer make sense for shareholders to support long-term corporate projects. Because the market discounts the value of future profits, shareholders who plan to sell

100. Lynn A. Stout, The Unimportance of Being Efficient: An Economic Analysis of Stock Market Pricing and Securities Regulation, 87 MICH. L. REV. 613, 644-49 (1988) (discussing relative unimportance of secondary stock market in allocating economic resources).

101. Id. For a contrary view, see Michael Jensen, The Agency Costs of Overvalued Equity and the Current State of Corporate Finance, 10 EuR. FIN. MGMT. 549 (2004) (arguing that secondary market inefficiency leads executives whose compensation is based on equity prices to manipulate prices or even commit fraud). It can be argued, however, that in such cases the fault lies less in an inefficient market and more in the use of stock-based compensation. See Lynn A. Stout, Killing Conscience: The Unintended Behavioral Consequences of 'Pay-for-Performance', 39 J. CoRP. L. (forthcoming 2014) (discussing dangers of "pay for performance" approach).

102. STOUT, supra note 21, at 66 . 
soon may calculate that they would do better if such projects were abandoned and the resources devoted to them were used elsewhere or, better yet, sold for cash that could be distributed as a dividend. In extreme cases, shareholders might want the entire company sold or liquidated.

As a hypothetical example, recall the oak groves of New College discussed in Part II.H. New College is, of course, a nonprofit. But suppose New College were a for-profit business corporation with shareholders. Suppose also that at some periods in its long history, shares of hypothetical New College Corp. traded at depressed prices. During these periods of depressed prices, shareholders in New College Corp. who wanted to sell in the near future might reasonably have concluded that the best way to maximize their wealth would be to have New College Corp. cut down its oaks, sell them for timber, and distribute the cash from the sale in a dividend. This would have been a regrettable mistake from the perspectives of New College and its future shareholders, who want the oaks to be available when dining hall repairs become necessary in the future. But the state of the dining hall decades or centuries hence would be of no concern to New College shareholders planning to sell undervalued shares in the near future.

\section{G. The Downside of Shareholder Value Thinking}

Of course, if New College Corp. were a board-managed company with effective lock-in, decisions about what to do with the oak groves and whether or not to pay dividends would not have been made by its shareholders. They would have been made by its board of directors. And unlike New College Corp.'s shareholders, the members of the board would not have gained financially from cutting down the oaks, even at times when the market undervalued New College Corp. shares. ${ }^{103}$ As a result, while the board of New College Corp. controlled the oak groves, the oaks would have been at far less risk of being cut down before their time. ${ }^{104}$

The example of New College Corp. illustrates how managerialist companies governed by boards are less likely to terminate long-term corporate projects prematurely. However, shareholders in public companies today enjoy far more influence over boards than they enjoyed in the managerialist era. Executive compensation practices have also changed,

103. Although directors who are also shareholders may hope to profit from "unlocking shareholder value" by cutting down the oaks, directors' fees in and of themselves typically are not tied to share price performance.

104. To the contrary, directors' incentives favor pursuing the project. See supra note 66 (discussing directors' incentives and motivations). 
and executives' financial incentives are much closer to shareholders'. Logic suggests such shifts make it harder for public corporations to keep their assets locked in. And, unless stock markets are perfectly fundamental value efficient - which is unlikely for the reasons discussed in Part III.B-loss of asset lock-in threatens public companies' ability to pursue long-term projects.

Without lock-in, public corporations become delicate creatures. All it takes is a market that temporarily undervalues the company's shares, and shareholders who plan to sell in the near future may ask the board to abandon long-term plans and instead pursue strategies calculated to produce immediate share price gains. For example, shareholders may ask boards to cut expenses for marketing, research, and employee development; take on debt to fund a large dividend or share repurchase program; or even sell off all or part of the company. Moreover, even if a company's existing shareholders are patient, an undervalued firm risks attracting unwanted attention from short-term investors, like hedge funds, that can buy on the open market for the sole purpose of pressuring boards to pursue such measures. ${ }^{105}$ Finally, even if the board is willing and able to resist activist shareholder demands, executives whose wealth and income are tied to shareholder returns may themselves lobby the board to chase short-term price appreciation rather than long-term growth.

With such powerful constituents pushing boards to "unlock shareholder value," it becomes far more difficult for public corporations to pursue long-term projects. After all, long-term projects by definition require years or decades to reach fruition. Without asset lock-in, a single period of significant share undervaluation during those years or decades may derail the project. Knowing this, directors and executives of public companies without effective lock-in will likely avoid making long-term investments in the first place. ${ }^{106}$ The eventual result is reduced returns for future generations of shareholders.

Recognizing the public business corporation's role as an institution for efficient intertemporal exchange of resources between generations offers a new perspective on the wisdom of embracing "shareholder democracy" and "maximizing shareholder value" as corporate objectives.

105. See William W. Bratton, Hedge Funds and Governance Targets, 95 GeO. L.J. 1375, 1401 (2007) ("Activist hedge funds look for four things in their targets - potential sale of the whole, potential sale of a part, free cash, and cuttable costs.").

106. As an example, Exxon Mobil was initially interested in developing algal biofuels. However, it dropped the project when it concluded that it was likely twenty-five years or more away from commercial viability. Joe Carroll, Exxon at Least 25 Years Away from Making Fuel from Algae, BLOOMBERG (Mar. 8, 2013, 1:11 PM), http://www.bloomberg.com/news/2013-03-08/exxon-at-least25-years-away-from-making-fuel-from-algae.html. 
Whether or not the embrace of shareholder primacy has benefited today's shareholders by reducing managerial agency costs - and given continued growth in executive compensation in the face of weak shareholder returns, there is every reason to question whether it has ${ }^{107}$ - shareholder primacy may have a much larger economic cost if it destroys the public corporation's ability to invest efficiently in the future.

\section{H. Signs of Trouble}

Unfortunately, there are signs the destruction has begun. These signs include (1) the prevalence of corporate share repurchases over share issuances; (2) a decline in the population and life expectancy of public corporations; (3) reduced returns to equity investors in public corporations; and (4) expressions of concern that American public companies are becoming less innovative. Let us consider each in turn.

In the managerialist era, boards and executives often embraced growth as a corporate objective. ${ }^{108}$ With today's emphasis on "unlocking shareholder value," many American companies have adopted the opposite strategy. Rather than accumulating resources, they are now unlocking assets and distributing cash to shareholders. This trend can be seen when we compare corporate issuances with corporate share repurchases. From 1993 on, American nonfinancial companies have routinely disgorged $\$ 50$ to $\$ 200$ billion more in cash annually to shareholders through repurchase programs than they have raised through equity issuances. ${ }^{109}$ This conservative figure excludes corporate cash disgorged to shareholders through dividends.

If these cash transfers to shareholders are being made at the expense of retaining adequate corporate resources to protect against downside risk and invest for the future, they make it harder for American public companies to survive and thrive. Supporting this hypothesis, American public companies are becoming both fewer and more fragile. Over the last fifteen years the population of U.S. listed firms has dropped by more than half, from nearly 9,000 firms in the late 1990 s to only around 4,000

107. See BEBCHUK \& FRIED, supra note 68, at 1-22 (discussing strong growth in executive compensation over the past two decades); see also infra text accompanying note 113 (discussing declining investor returns over the past two decades).

108. Indeed, shareholder primacists cited such "empire building" as a flaw of managerialism. Rock, supra note 60, at 1915.

109. See Bd. of Governors of the Fed. Reserve Bd., Monetary Policy Report to CONGRESS 14 (2005), available at http://www.federalreserve.gov/boarddocs/hh/2005/

february/ReportSection2.htm (referencing table entitled "financing gap and net equity retirement at nonfinancial corporations"). See also Rock, supra note 60, at 1919 (noting that from 1984 to 1990, about $3 \%$ of net public equity was returned each year, with this trend continuing into $2000 \mathrm{~s}$ ). 
today. ${ }^{110}$ Meanwhile, the life expectancy of large companies has been cut by more than $75 \%$. In the mid-twentieth century, the average Fortune 500 company could expect to remain on that list for sixty years or more. Today the average Fortune 500 firm stays in the 500 for only fifteen years. $^{111}$

If public companies today are in fact emphasizing short-term share price gains at the expense of long-term investment, we also can expect to see, in due time, reduced returns to investors. Again, this seems to be happening. Shareholder value thinking gained serious legal traction in the early 1990s with the SEC's 1992 proxy rule amendments (which paved the way for activist institutional investors) and Congress' 1993 tax code change (which encouraged executive pay to be tied to share price). ${ }^{112}$ In the years immediately following, shareholders in public companies saw an initial increase in their returns. So too would hypothetical shareholders of New College Corp. if they owned undervalued shares at a time when its oaks were cut down and sold for timber. But even including gains from the late 1990s bull market, returns from holding public equity have been significantly lower in the shareholder-centric era than under managerialism. During the four decades from 1954 to 1993, inflation-adjusted total returns to holding the S\&P 500 averaged $7 \%$ annually. In the two decades since, shareholders have done significantly worse, earning average inflation-adjusted returns of only $6.5 \%$ annually. ${ }^{113}$

It can of course be argued that declining shareholder returns are due to some cause other than the business world's embrace of shareholder primacy. Yet in addition to the objective facts - massive share repurchase programs, declining numbers of public companies, reduced corporate life span, diminished investor returns - there is a widespread subjec-

110. Gerald F. Davis, After the Corporation, 4 POL. \& SoC’Y 283, 291 (2013) (Fig. 2, U.S. Listed Companies).

111. Steve Denning, Peggy Noonan on Steve Jobs and Why Big Companies Die, FORBES (Nov. 19, 2011, 7:22 AM), http://www.forbes.com/sites/stevedenning/2011/11/19/peggy-noonan-on-stevejobs-and-why-big-companies-die/. See generally The Endangered Public Company, THE ECONOMIST (May 19, 2012), http://www.economist.com/node/21555562. Before dismissing the disappearance of public companies as evidence of Schumpeterian "creative destruction," it is important to recognize that if the destruction were creative it should be generating higher returns to shareholders. See infra text accompanying note 113 (equity returns are declining).

112. See Stout, supra note 86, at 1176 (discussing change to tax code); see also Anabtawi \& Stout, supra note 93, at 1276-77 (discussing change to proxy rule).

113. This calculation can be performed using the Dow Jones total return S\&P 500 calculator, available at http://dqydj.net/sp-500-return-calculator/, and calculating total inflation adjusted returns with dividends reinvested from January of 1954 until December of 1993, and from January of 1994 until December of 2013. 
tive perception that U.S. corporations are no longer pursuing the sorts of transformative research projects that were the hallmark of great American companies during the twentieth century. Companies like AT\&T, GE, Kodak, Xerox, Procter \& Gamble, DuPont, and U.S. Steel used to maintain large divisions devoted to research with little immediate commercial application. Today, the great corporate research labs of the managerialist era have become shadows of their former selves as employees are cut and the focus is shifted from pure research to modest projects with immediate profit potential. ${ }^{114}$ Where in the 1950s American corporations retained $60 \%$ of their profits for research and development, today they retain less than $10 \% .{ }^{115}$ Companies that attempt to build cash cushions to fund large-scale future projects are targeted by activist hedge funds demanding the cash be distributed to shareholders today. ${ }^{116}$

Logic and empirical data both support the claim that shareholder primacy threatens the public corporation's ability to invest for future generations. If further evidence is desired, consider a prominent counterexample: Google. In the spirit of the great twentieth century American corporations, Google is boldly pursuing large research projects devoted to developing robots and self-driving cars. ${ }^{117}$ Google can do this despite today's shareholder value ideology because, unlike most contemporary Fortune 500 firms, its assets are strongly locked in. When Google went public, it used a "dual class" share structure that allowed its founders and top executives to keep voting control. ${ }^{118}$ Google's outside shareholders are arguably even more powerless than the disbursed individual shareholders of the managerialist era.

Adopting a dual class structure like Google's is not a realistic option for most existing public companies. ${ }^{119}$ But Google's example, to-

114. See, e.g., Bill Buxton, The Price of Forgoing Basic Research, BUSINESSWEEK (Dec. 17, 2008), http://www.businessweek.com/stories/2008-12-17/the-price-of-forgoing-basic-research businessweek-business-news-stock-market-and-financial-advice; The Rise and Fall of Corporate R\&D: Out of the Dusty Labs, THE ECONOMIST (Mar. 1, 2007), http://www.economist.com/node/ 8769863.

115. David Ciepley, Beyond Public and Private: Toward a Political Theory of the Corporation, 107 AM. POL. SCI. REV. 139, 149 (2013) (citing remarks of Jack Jacobs).

116. See, e.g., Ray Tiernan, Activist Icahn Oversteps with Apple Buyback Demand, BARRON's (Oct. 26, 2013), http://online.barrons.com/news/articles/SB500014240531119048971045791494919 09420008. Icahn is only one of several activists that have targeted Apple.

117. See Berr, supra note 36; see also Humphrey, supra note 73.

118. See Stout, supra note 86, at 1182 (discussing Google).

119. Moreover, dual class structures raise their own problems. For example, it is unclear how a dual class company can maintain its forward-looking focus when its original controlling shareholders and executives die or retire. A similar problem can be seen in family-controlled firms, which are especially common outside the United States. Questions of succession and legacy loom large and threaten the long-term survival of the corporate entity when control of a family corporation passes 
gether with the observation that the relatively few companies that do go public today increasingly prefer dual class structures, suggests that entrepreneurs and business people recognize that public corporations run according to the principles of shareholder primacy are fragile and dysfunctional entities, incapable of pursuing long-range plans. Shareholder value thinking appears toxic to many, and perhaps most, public corporations. ${ }^{120}$

\section{CONCLUSION}

Modern discussions of corporate governance tend to implicitly assume that the question of how to best organize and govern corporations should be viewed from the perspective of what best serves the interests of today's shareholders (if one is a shareholder primacy advocate) or today's shareholders and other "stakeholders" (if one subscribes to some variant of stakeholder theory). Yet in thinking about how corporations contribute to social welfare, there is no reason we must consider only the welfare of those currently alive. Other generations can count, too. And while we cannot do much to benefit the dead, by using the corporate form we may be able to benefit not only those who are living, but also those who will live in the future.

This Symposium Article has suggested that the corporate form can be understood as a legal technology that has functioned historically as a vehicle for transferring wealth forward in time to benefit future generations. More recently, one kind of corporation - the public business corporation - has also developed the capacity to transfer wealth that will be created in the future backward in time to the present, where it appears as a higher share price today. This ability to transfer wealth in both temporal directions encourages investment in very large scale, very longterm enterprises. ${ }^{121}$ And very large-scale, long-term enterprises are of enormous significance to human welfare.

into the hands of a third or fourth generation. The great success of twentieth-century American corporations compared to those of other nations suggests that public companies run by managerialist boards whose members are selected for qualities like character, reputation, and the desire to leave a legacy may be superior at pursuing long-range investment plans to family-controlled companies where control is determined by genetic lottery. See STOUT, supra note 21, at 56; see also Stout, supra note 67, at 20-23 (2003) (discussing director selection). Public ownership structures also have the advantage of allowing the general population to participate in the wealth generation made possible by corporate entities.

120. See generally Stout, supra note 86 (discussing toxic effects of shareholder value thinking).

121. This may explain why there are relatively few publicly traded corporations. See supra text accompanying note 110 (about 4000 public companies in the United States). By contrast there are several million private companies that file corporate tax returns. U.S. CENSUS BUREAU, StATisticAl ABStRACT OF THE United StATEs: 2012, at 491 (2012), available at 
One implication is that if the corporate form in general, and the public business corporation in particular, had never developed, the present generation of human beings likely would be far worse off than they are today. Of course, creating an immortal entity capable of accumulating enormous resources, and granting it legal and political rights, raises "Frankenstein's monster" issues that must be taken seriously. We do not want the corporate creation to destroy the creator. ${ }^{122}$ Such issues lie beyond the scope of this Symposium Article, but they are important and should be addressed. Yet history demonstrates that corporations have great potential to do good for humanity. Without corporations, fewer universities would have been founded and fewer cathedrals built, and fewer still would have survived to delight, inspire, and educate multiple generations. We would have far fewer roads, canals, and railroads, and thus less commerce and exchange. We would probably not enjoy the benefits of the transistor, computer, commercial aviation, readily available antibiotics and antivirals, or the Internet-at least not unless such innovations were developed and provided solely by government entities, an unlikely scenario in a capitalist democracy. ${ }^{123}$

A second implication is that, if we do not continue to have thriving corporations, and especially thriving business corporations with asset lock-in and transferable shares, future generations will be left worse off than they could, or should, be. Our society confronts a variety of serious problems likely to be solved only by investing massive amounts of resources over long periods of time: disappearing ecosystems, increasing

http://www.census.gov/prod/2011pubs/12statab/business.pdf (specifically Table 744, Number of Tax Returns, Receipts, and Net Income by Type of Business: 1990-2008, indicating 5.8 million corporate tax returns for 2008). Because many private companies have a controlling shareholder, they have only a limited capacity to aggregate and lock in assets, suggesting there is some reason other than scale and longevity why their founders are choosing the corporate form. Limited shareholder liability is one obvious explanation.

122. See Louis K. Liggett Co. v. Lee, 288 U.S. 517, 548, 567 (1933) (Brandeis, J., dissenting in part) (describing the corporation as a "Frankenstein monster which states have created by their corporation laws").

123. See supra text accompanying note 30 (discussing obstacles to long-term government investment in a capitalist democracy). Like corporations, governments are "sempiternal" entities that have the potential to pursue long-term projects through multiple generations of human agents. Although an exploration of the complex relationship between corporations and governments lies well beyond the scope of this Symposium Article, see, e.g., Ciepley, supra note 28 (arguing that the idea of government has roots in corporate concepts) and Ciepley, supra note 115 (arguing that modern business corporations can be viewed as "franchise governments"), it should be noted that while public business corporations can substitute for governments in pursuing long-term investments, governments and business corporations can also play complementary roles. For example, while the Federal government decided to build and provide funding for the Hoover Dam in the 1930s, the dam itself was constructed by for-profit entities. See generally MOWERY \& ROSENBERG, supra note 35 (discussing combined roles of corporations, governments, and universities in fostering innovation). 
demands for energy, chronic diseases like diabetes and hypertension, rising carbon levels in our atmosphere and our oceans. Corporations in general, and particularly public business corporations with asset lock-in, are especially well suited to solving such long-term problems.

If we care about intergenerational equity and intergenerational efficiency, we should protect and preserve the legal invention known as the corporation. Nonprofit entities seem to be doing at least as well as they historically have done. But the picture is not so rosy when it comes to public business corporations. There is reason to suspect that, as a result of widespread misunderstanding of their nature and purpose, large public corporations are becoming an endangered species. Their decline poses a challenge to our own species as well. 